\title{
Pesantren:
}

\section{Genealogi, Dinamika, dan Nasionalisme}

\author{
Jamil Abdul Aziz \\ Fakultas Tarbiyah Institut PTIQ, Jakarta, Indonesia \\ jamilabdulaziz@ptiq.ac.id
}

\begin{abstract}
Abstrak:
Artikel ini menjelaskan mengenai tiga hal penting terkait dengan pesantren di Indonesia. Pertama, mengenai genealogi: yaitu asal-usul munculnya pesantren di Indonesia yang multikultur. Kedua, dinamika pendidikan pesantren dari masa ke masa, bagaimana pesantren mampu mempertahankan dan bahkan mengembangkan eksistensinya di tengah-tengah arus pendidikan modern yang kian menggebu. Ketiga, apa yang menjadi kunci pesantren, khususnya yang dikembangkan oleh para kyai Nahdliyin, sehingga mampu mencetak generasi nasionalis yang turut serta mengawal keutuhan Negara Kesatuan Republik Indonesia (NKRI). Artikel ini menggunakan pendekatan penelitian pustaka (library research) dan analisis historis dalam mengurai pembahasannya.
\end{abstract}

Kata Kunci: Pesantren, Genealogi, Dinamika, Nasionalisme

\begin{abstract}
:
This paper adresses three things related to pesantren (Islamic traditional education system) in Indonesia. First, elements genealogy: the origin of the emergence of multicultural pesantren in Indonesia. Second, the dynamic elements of pesantren education from time to time, how schools are able to maintain growth and existence amidst currents of modern education is increasingly passionate. Third, what are the key elements of pesantren, especially developed nationalizm by kyai Nahdliyin, so as to print the generation that participated guarding the integrity of the Unitary Republic of Indonesia (NKRI).
\end{abstract}

Keywords: Pesantren, Genealogy, Dynamics, Nationalism 


\section{Pendahuluan}

Indonesia sebagai negara mayoritas muslim terbesar di dunia ${ }^{1}$, memiliki catatan penting dalam dinamika pengembangan islamisasi. Di samping itu, Indonesia menjadi sorotan menarik di mata publik Internasional. Karena, Indonesia sejauh ini cenderung mampu meminimalisasi konflik dan menjalin kehidupan yang harmonis di tengah-tengah beragamnya suku, agama, budaya, dan bahasa yang ada. Hal tersebut, tentunya tidak bisa dipisahkan dari peranan para alim ulama dan cendekiawan muslim dengan notabene sebagai penda'i dan pendidik yang kemudian mengembangkan syi'arnya melalui berbagai lembaga pendidikan. Salah satunya, yang paling utama adalah melalui jalur pondok pesantren yang kemudian menjadi lembaga pendidikan tertua di Indonesia.

Oleh karena itu, secara historis tidak bisa dipungkiri bahwa pesantren yang merupakan warisan berharga dari Wali Songo, yang kemudian dilanjutkan oleh para kyai Nahdliyin. Sampai saat ini, kian "mendarah daging" dan memiliki peranan penting dalam pembentukan sikap keagamaan masyarakat yang multikultur. Sehingga out-putnya bisa melahirkan generasi yang ikut serta menjaga keutuhan Negara Kesatuan Republik Indonesia (NKRI) yang terdiri dari ragam suku, agama, budaya, dan bahasa. Dengan demikian, sebagaimana yang diungkapkan oleh Nurcholish Madjid, pesantren yang ada di Nusantara, tidak hanya identik dengan makna keislaman, tetapi juga mengandung makna keaslian Indonesia (indigenous). ${ }^{2}$

Jika dilihat dari sisi fungsionalnya, pesantren memiliki dua fungsi: yaitu sebagai lembaga penyiaran keagamaan dan sebagai lembaga pendidikan. Dalam artikel ini, penulis tidak hanya membahas pesantren sebagai lembaga penyiaran agama. Akan tetapi, juga sebagai lembaga pendidikan. Sepanjang abad ke-18 sampai dengan abad ke-20, pesantren semakin dirasakan keberadaannya oleh masyarakat secara luas, sehingga kemunculan pesantren di tengah masayarakat selalu direspons positif oleh masyarakat. ${ }^{3}$

Lebih jauh lagi, eksistensi dan kiprah pesantren di Indonesia telah diakui di panggung nasional, pesantren telah mampu mencetak generasi yang turut serta membangun kemajuan dan mempertahankan kedaulatan bangsa. Keputusan Presiden (Keppres) Nomor 22 Tahun

\footnotetext{
${ }^{1}$ Berdasarkan catatan The Pew Forum on Religion \& Public Life tahun 2010 Indonesia menempati urutan pertama negara dengan mayoritaspenduduk muslim di dunia. Jumlahnya sekitar 205 juta jiwa, artinya 88,1 \% penduduk Indonesia beragama Islam. Di urutan selanjutnya ada Pakistan, India, Bangladesh, Mesir, Nigeria, Iran, Turki, Algeria, Maroko, (Angga Indrawan, 10 Negara dengan Populasi Muslim Terbesar di Dunia, Republika.com). Diakses 7 Desember 2016

${ }^{2}$ Nurcholish Madjid, Bilik-Bilik Pesantren: Sebuah Potret Perjalanan, (Jakarta: Penerbit Paramadina, 1997), Cet-1, h.3

${ }^{3}$ Zuhairini, ed. Sejarah Pendidikan Islam, (Jakarta: Bumi Aksara, 1992), h. 212
} 
2015 tentang penetapan 22 Oktober sebagai Hari Santri Nasional (HSN) adalah sebagai bukti dan isyarat (sign) secara formal dan nasional bahwa pesantren itu "ada" dan kedudukannya par-excellence.

Kontribusi pesantren di Indonesia telah melintasi batas-batas ruang sosial dan keagamaan. Pesantren tidak hanya mengurusi ruang ritual keagamaan semata, lebih dari itu mampu mengambil peran penting untuk senantiasa merawat tanah air, agar tidak terus menerus dieksploitasi orang-orang asing dari dari serangan pribumi yang hendak menghancurkan kebhinekaan. Dengan demikian, pandangan Azyumardi Azra yang menyatakan bahwa fungsi pesantren jangan hanya berkutat di transmisi-transfer ilmu-ilmu Islam, pemeliharaan tradisi Islam, dan reproduksi ulama semata, ${ }^{4}$ sudah terjawab oleh fakta yang menunjukkan bahwa pesantren mampu bersaing dan berkontribusi secara lebih luas.

Akan tetapi, menurut pandangan penulis, sampai saat ini masih banyak dari kalangan masyarakat pada umumnya, bahkan di kalangan pesantren sendiri, yang belum mengetahui dan memahami dengan baik bagaimana sejarah dan asal-usul (genealogi) pesantren sebagai lembaga pendidikan, lahir dan berkembang di Indonesia. Seperti apa dinamika pendidikan yang dialami oleh pesantren dari masa ke masa dan apa kuncinya sehingga pesantren masih tetap bisa eksis dan senantias berkembang di tengah-tengah arus modernisasi yang kian menggebu. Hal ini, bagi penulis penting dipahami terutama bagi kalangan aktivis keagamaan dan para pendidik, agar kita bisa mengambil nilai dan pelajaran dari perjalanan dan lika-liku yang telah dilalui oleh pesantren sebagai barometer dalam membentuk generasi yang progresif, inklusif, plural, dan toleran.

Di samping itu, sampai saat ini masih banyak masyarakat yang belum memahami apa sebenarnya keunggulan pesantren sebagai lembaga pendidikan dibandingkan dengan lembaga pendidikan yang lain pada umumnya, terutama perannya dalam menjaga keutuhan NKRI. Hal ini penting dibahas dan dikaji secara komperehensif, setidaknya karena dua alasan mendasar. Pertama, karena tidak sedikit paradigma masyarakat, khususnya orang tua santri yang menilai pesantren hanya sebagai "bengkel anak nakal" bukan karena meyakini bahwa pesantren memiliki kualitas dan keunggulan dibanding dengan sekolah umum. Tentu, hal tersebut tidak berarti menafikan adanya sebagian masyarakat dan orang tua yang mengirimkan anak-anaknya ke pesantren, agar anaknya pandai secara intelektual dan spiritual.

Kedua, keunggulan pesantren perlu dipahami dan disadari dengan baik oleh kalangan

\footnotetext{
${ }^{4}$ Azyumardi Azra, Pendidikan Islam: Tradisi dan Modernisasi di Tengah Tantangan Milenium, (Jakarta: Kencana Prenada Media Grup, 2012), h.127
} 
masyarakat, terkhusus kalangan pesantren sendiri, agar keunggulan-keunggulan yang dimiliki oleh pesantren bisa lebih dioptimalkan potensinya. Terutama, saat ini tantangan pesantren semakin besar, dikarenakan banyaknya gerakan-gerakan fundamentalis dan kapitalis, yang hendak menghancurkan tradisi-tradisi dan kearifan lokal yang ada di Nusantara.

Berangkat dari hal-hal di atas, penulis dalam hal ini berusaha merespon problematika yang ada dan mengurai mengenai asal-usul, perjalanan, dan keunggulan pesantren sebagai lembaga pendidikan tertua di Indonesia. Artikel ini menggunakan pendekatan penelitian pustaka (library research) dan analisis historis. Harapannya, artikel ini bisa menjadi referensi dalam menambah khazanah dan wawasan (insight) dalam bidang pendidikan Islam dan kebangsaan.

\section{Genealogi (Asal-Usul) Munculnya Pesantren di Indonesia}

Mengenai asal-usul dan latar belakang (genealogi) munculnya pesantren di Indonesia, terjadi perbedaan pendapat di kalangan para ahli sejarah. Apakah pesantren lahir dari budaya Islam secara murni, ataukah hasil dari akulturasi budaya dengan pendidikan Hindu-Budha pada masa sebelum Islam. Sepanjang pengamatan penulis, setidaknya ada tiga pandangan mengenai asal usul lahirnya pesantren di Indonesia yang bisa dijadikan pijakan. Hal tersebut, di antaranya:

\section{Pertama: Pesantren berasal dari Tradisi Tarekat Islam}

Pandangan pertama, menyatakan bahwa pesantren di Indonesia diyakini berasal dari tradisi Islam sendiri, yaitu tradisi tarekat. Pandangan ini dikaitkan dengan fakta bahwa penyebaran Islam di Indonesia pada awalnya banyak dikenal dalam bentuk kegiatan tarekat dengan dipimpin oleh kyai. Salah satu kegiatan tarekat adalah mengadakan suluk, melakukan ibadah di masjid di bawah bimbingan kyai. ${ }^{5}$ Untuk keperluan tersebut, kyai menyediakan ruang-ruang khusus untuk menampung para santri.

Para pengikut tarekat selain diajarkan amalan-amalan tarekat mereka juga diajarkan kitab agama dalam berbagai cabang ilmu pengetahuan agama Islam. Dalam hal ini, Syaikh Maulāna Mālik Ibrāhīm atau Sunan Gresik dipandang sebagai ulama pertama yang membangun lembaga pengajian yang merupakan cikal bakal berdirinya pesantren sebagai tempat mendidik dan menggembleng para santri. Tujuannya adalah agar para santri menjadi

${ }^{5}$ Abdul Aziz, et al., Ensiklopedi Islam IV (Jakarta: Ichtiar Baru Van Hoeve, 1994), Cet-II, h. 103. Pendapat ini juga didukung oleh Zamakhsyari yang berpendapat bahwa pesantren, khususnya di Jawa, merupakan kombinasi antara madrasah dan pusat kegiatan tarekat, bukan antara Islam dengan Hindu. Lihat: Zamakhsyari Dhofier, Tradisi Pesantren: Studi tentang Pandangan Kyai, h. 25 
juru dakwah yang mahir sebelum mereka diterjunkan langsung di masyarakat luas. Usaha Syaikh menemukan momuntem seiring dengan mulai runtuhnya singgasana kekuasaan Majapahit (1293 - 1478 M). Islam pun berkembang demikian pesat, khususnya di daerah pesisir yang kebetulan menjadi pusat perdagangan antar daerah bahkan antar negara. ${ }^{6}$

Hasil penelusuran sejarah ditemukan sejumlah bukti kuat yang menunjukkan bahwa cikal bakal pendirian pesantren pada awalnya terdapat di daerah-daerah pesisir sepanjang pantai utara Jawa, seperti Giri (Gresik), Ampel Denta (Surabaya), Bonang (Tuban), Kudus, Lasem, dan Cirebon. Kota-kota tersebut pada waktu itu merupakan kota kosmopolitan yang menjadi jalur penghubung perdagangan dunia, sekaligus tempat persinggahan para pedagang dan muballig Islam yang datang dari Jazirah Arab seperti Hadramaut, Persia, dan Irak. ${ }^{7}$

Kedua: Pesantren berasal dari Model Pendidikan Timur Tengah

Kedua, sebagian kalangan menyatakan bahwa kehadiran pesantren di Indonesia diilhami oleh lembaga pendidikan "kuttab", yakni lembaga pendidikan pada masa kerajaan Bani Umayyah yang semula hanya merupakan wahana atau lembaga baca dan tulis dengan sistem "halaqah". Pada tahap berikutnya lembaga ini mengalami perkembangan pesat, karena didukung oleh iuran masyarakat serta adanya rencana-rencana yang harus dipatuhi oleh pendidik dan anak didik. ${ }^{8}$ Pendapat ini hampir sama dengan pendapat yang menyatakan pesantren diadopsi dari lembaga pendidikan Islam Timur-Tengah, yaitu al-Azhār di Kairo, Mesir. ${ }^{9}$

Ketiga: Pesantren berasal dari Tradisi Pendidikan Hindu-Budha

Pendapat selanjutnya, menyatakan bahwa pesantren yang ada sekarang merupakan pengambil-alihan dari sistem "mandala" dan asrama orang-orang Hindu di Nusantara pada masa sebelum Islam, dimana asrama tersebut dimaksudkan sebagai tempat mengajarkan ajaran-ajaran agama Hindu serta tempat membina kader-kader penyebar agama tersebut. ${ }^{10}$ Pesantren sendiri, dalam hal ini dipandang sebagai kreasi sejarah anak bangsa, pesantren merupakan sistem pendidikan Islam yang mengadopsi dari sistem pendidikan Hindu-Budha

${ }^{6}$ Alwi Shihab, Islam Inklusif, (Bandung: Mizan, 2002), Cet-1, h. 23.

${ }^{7}$ Fatah Syukur, Dinamika Pesantren dan Madrasah (Yogyakarta: Pustaka Pelajar, 2002), Cet-I, h. 248

${ }^{8}$ Lihat: Muhaimin, et al., Pemikiran Pendidikan Islam (Bandung: Tri Genda Karya, 1993), Cet- III, h.298299.

${ }^{9}$ Martin Van Bruinessen, salah seorang yang mendukung versi ini berpandangan bahwa pesantren cenderung lebih dekat dengan salah satu model sistem pendidikan di al-Azhār. Artinya, menurut pendapat ini ada sisi kesamaan dari segi penyampaian ilmu pengetahuan agama, yakni melalui metode halaqah, di mana kyai dan santri berkumpul dalam satu tempat untuk melakukan pengajian. Kelompok ini meragukan kebenaran pendapat yang menyatakan bahwa lembaga mandala dan asrama yang ada sudah sejak zaman Hindu-Budha merupakan tempat berlangsungnya praktik pengajaran tekstual sebagaimana di pesantren. Lihat: Hanun Asrohah, Sejarah Pendidikan Islam (Cet. I; Jakarta: Logos Wacana Ilmu, 1999), h. 184.

${ }^{10}$ Abdul Aziz, et al., Ensiklopedi Islam IV, h. 104 
dan mengubahnya menjadi pendidikan keislaman. ${ }^{11}$

Hal tersebut, menurut CC. Berg, sebagaimana yang dikutip oleh Zamakhsyarie Dhofir, dapat dilihat dari istilah "santri" itu sendiri yang berasal dari "shastri", bahasa India, yang berarti orang yang tahu buku-buku suci agama Hindu, atau seorang sarjana ahli kitab suci agama Hindu. ${ }^{12}$ Menurut Sa'id Aqil Siradj, peralihan kata "shastri” menjadi "santri” diadopsi oleh Wali Songo, sebagaimana misalnya "syahadatain" dari bahasa Arab menjadi "sekaten" dalam bahasa Jawa. ${ }^{13}$ Dari kata dasar "santri" yang dibubuhi awalan "pe" dan akhiran "an" lahirlah kemudian istilah "Pesantren" yang berarti tempat tinggal para santri. ${ }^{14}$ Kata pondok sendiri yang dipakai dalam bahasa Indonesia, ada kemungkinan berasal dari bahasa arab "fundūk" yang berarti ruang tempat tidur, wisma atau hotel sederhana. Pada umumnya, pondok memang merupakan tempat penampungan sederhana bagi para pelajar yang jauh dari tempat asalnya. ${ }^{15}$

Dari ketiga pendapat dan pandangan di atas, menurut analisa penulis masing-masing memiliki sisi kebenaran yang dapat dipertemukan. Pendapat yang menyatakan bahwa pesantren berasal dari tradisi Hindu, ada benarnya jika memang diterima bahwa nama pesantren sendiri berasal dari bahasa India atau berasal dari bahasa Sansekerta. Kemudian, pendapat yang mengatakan bahwa pesantren tumbuh dari tradisi sufi juga dapat diterima, jika dilihat dari fakta sejarah yang menujukkan bahwa tradisi pesantren mempunyai kesamaan dengan praktek hidup yang dijalani oleh kaum sufi. Adapun pendapat yang mengatakan bahwa pesantren diadopsi dari tradisi pendidikan di Timur Tengah, ada benarnya juga karena realitanya orang yang mula-mula mengembangkan pesantren adalah mereka yang menimba ilmu di Timur Tengah terutama di Mekah dan di Mesir.

Nurcholish Madjid sendiri, ketika menyatakan bahwa pesantren memiliki makna keaslian Indonesia (indegenous) karena berasal dari tradisi Hindu-Budha, tetap tidak menafikan bahwa pesantren erat dengan tradisi islam yaitu tarekat. Islam datang ke kawasan ini (Indonesia) melalui gerkan kesufian dan tarekat-tarekat. ${ }^{16}$ Kegiatan tasawuf yang berada di pondokan yang berkembang di indonesia, seperti menampung fakir yang hendak melakukan wirid atau suluk. Dalam perkembangannya menjadi pusat-pusat kegiatan ekonomi, pendidikan,

\footnotetext{
${ }^{11}$ Lihat: Zamakhsyari Dhofier, Tradisi Pesantren: Studi tentang Pandangan Kyai h. 10 dan Nurcholish Madjid, Bilik-Bilik Pesantren: Sebuah Potret Perjalanan (Jakarta: Paramadina, 1997), Cet-I h. 5.

${ }^{12}$ Zamakhsyari Dhofier, Tradisi Pesantren: Studi tentang Pandangan Kyai (Jakarta: LP3ES, 1997), CetVII, h. 18

${ }^{13}$ Ibi Syatibi, ed. Pendidikan Karakter Berbasis Tradisi Pesantren, (Jakarta: Rumah Kitab, 2014), h.ix

${ }^{14}$ Zamakhsyari Dhofier, Tradisi Pesantren, h. 18.

${ }^{15}$ Manfred Ziemek, Pesantren dalam Perubahan Sosial (Jakarta: P3M, 1986), Cet- I, h. 98-99.

${ }^{16}$ Nurcholish Madjid, Islam Agama Peradaban: Membangun Makna dan Relevansi Doktrin Islam Dalam Sejarah, (Jakarta: Paramadina, 2008), Cet-III, h. 91
} 
bahkan cika-bakal kekuatan politik yang berpengaruh. Zawiyah atau pondokan ini pada gilirannya berkembang menjadi pondok pesantren. ${ }^{17}$

Munculnya beberapa pendapat tersebut, disebabkan karena tidak tersedianya sumber tertulis yang dapat meyakinkan semua pihak. Akan tetapi, menurut penulis perbedaan sudut pandang dalam memahami latar belakang lahirnya pesantren bukanlah sesuatu yang bersifat kontradiktif dan menimbulkan permasalahan. Akan tetapi, tetap mampu dipersatukan dan dipertemukan titik kesamaannya sehingga melahirkan sebuah harmoni dan kearifan tersendiri bagi dunia pesantren.

Perbedaan pendapat mengenai asal-usul munculnya pesantren, bisa ditarik ke arah yang bersifat filosofis. Pesantren yang dipandang sebagai lembaga yang lahir dari tradisi Islam, tradisi timur-tengah, dan tradisi hindu, bisa menjadi kunci bahwa pesantren mampu mengharmonikan berbagai macam tradisi, menghargai dan menyerap nilai-nilai dari lintas tradisi. Sehingga, pesantren mampu menciptakan keunikan yang khas dibanding dengan lembaga pendidikan yang lain. Inilah kemudian, yang menjadi modal pertama pesantren sebagai lembaga yang turut serta menghargai berbagai macam perbedaan.

\section{Dinamika Pendidikan Pesantren dari Masa ke Masa}

Setelah penulis menguraikan mengenai asal-usul munculnya pesantren di Indonesia. Di bagian ini, penulis akan uraikan secara singkat bagaimana dinamika yang ada di dunia pesantren dalam perspektif pendidikan di Indonesia. Serta, apa kuncinya pesantren sebagai lembaga pendidikan masih tetap eksis dan mampu bersaing dengan pendidikan umum, yang jika dilihat dari segi materialnya pendidikan umum lebih mapan. Hal ini, penting dipahami karena pada umumnya ketika kita membahas mengenai pesantren dan keterkaitannya dengan NKRI, banyak yang hanya membahas dari sisi romanistme heroik santri dan kyainya semata. Padahal, mencermati bagaimana pesantren mempertahankan dan mengembangkan eksistensinya tidak kalah penting. Karena dengan begitu, kita jadi memahami bukan hanya sebatas peranannya. Akan tetapi, juga memahami dinamika internal yang ada di dalamnya.

Pertama-tama, penulis akan menjelaskan terlebih dahulu mengenai pesantren tertua di Indonesia. Mengenai pesantren pertama atau tertua di Indonesia terdapat perbedaan pendapat di kalangan peneliti, baik nama pesantren maupun tahun berdirinya. Berdasarkan hasil pendataan yang dilakukan oleh Depatremen Agama pada 1984-1985 diperoleh informasi

\footnotetext{
${ }^{17}$ Lihat: Nurcholish Madjid, "Pesantren dan Tasawuf”, dalam Dawam Rahardjo, Pesantren dan Pembangunan, (Jakarta: LP3ES, 1995), h. 104
} 
bahwa pesantren tertua di Indonesia adalah Pesantren Jan Tanpes II di Pamekasan Madura yang didirikan pada tahun 1762. ${ }^{18}$ Akan tetapi, data dari Departemen Agama tersebut ditolak oleh Mastuhu. ${ }^{19}$ Sedangkan menurut Martin van Bruinessen, seperti yang dikutip oleh Abdullah Aly, bahwa Pesantren Tegalsari, salah satu desa di Ponorogo, Jawa Timur merupakan pesantren tertua di Indonesia yang didirikan tahun $1742 \mathrm{M} .{ }^{20}$ Perbedaan pendapat tersebut dikarenakan minimnya catatan sejarah mengenai yang menjelaskan tentang keberadaan pesantren secara valid dan komprehensif.

Terlepas dari pesantren mana yang paling tua dan pertama didirikan di Indonesia, pesantren di Indonesia berkembang pesat dari awal mula berdirinya, sampai masa penjajahan dan beberapa tahun setelah kemerdekaan. Sebagaimana yang dinyatakan oleh Yudian Wahyudi, bahwa peningkatan jumlah pesantren pada masa penjajahan Belanda berkembang pesat. Sayap ulama Diponegoro mendirikan pesantren sebagai benteng pertahanan jangka panjang di daerah pedesaan-pedesaan agar tidak terjangkau teknologi militer Belanda, dengan strategi total non-cooperation but non-violance dan menjadikan adat sebagian dari Islam, sehingga Islam menyatu dengan budaya. ${ }^{21}$

Akan tetapi, kejayaan kaum santri tidak berlangsung lama. Di Awal kemerdekaan, kaum santri memang masih terlihat unggul. Sebagian kyai, yang tidak memegang ijazah formal masih bisa menjadi dosen di perguruan tinggi (PT), bahkan menjadi professor. Namun demikian, peran "wong pondokan" ini segera diganti oleh "wong sekolahan", khususnya setelah Negara Republik Indonesia membangun "pabrik ijazah” di mana-mana. ${ }^{22}$

Singkat kata, awal tahun 1970-an kaum santri tersapu perubahan "radikal". Hampir tidak ada lagi kyai yang menjadi dosen agama Islam sekalipun di lingkungan perguruan tunggi umum (PTU). Bahkan, di lingkungan IAIN peran kaum kyai diambil alih oleh kaum doktorandus. Walaupun alim dan mahir kitab kuning, tetapi kyai tersingkir dari administrasi negara karena tidak punya ijazah formal. ${ }^{23}$

18 Departemen Agama RI., Nama dan Data Potensi Pondok-Pondok Pesantren Seluruh Indonesia,(Jakarta: Depag RI., 1984/1985), h. 668.

${ }^{19}$ Dia menolak informasi tersebut dengan alasan bahwa sebelum adanya Pesantren Jan Tapes II, tentunya ada Pesantren Jan Tanpes I yang lebih tua. Selain itu, Mastuhu menduga bahwa pesantren didirikan setelah Islam masuk ke Indonesia. Lihat: Mastuhu, Dinamika Sistem Pendidikan Pesantren: Suatu Kajian tentang Unsur dan Nilai Sistem Pendidikan Pesantren, (Jakarta: INIS, 1994), h. 19.

${ }^{20}$ Abdullah Aly, Pendidikan Islam Multikultural di Pesantren: Telaah terhadap Kurikulum Pondok Pesantren Modern Islam Assalam Surakarta (Yogyakarta: Pustaka Pelajar, 2011), Cet- I, h. 154-156. 2012), h. 77

${ }^{21}$ Yudian Wahyudi, Perang Diponegoro; Tremas, SBY dan Ploso, (Yogyakarta: Cakrawala Media,

${ }^{22}$ Yudian Wahyudi, Perang Diponegoro; Tremas, SBY dan Ploso, h. 15

${ }^{23}$ Yudian Wahyudi, Perang Diponegoro; Tremas, SBY dan Ploso, h. 16 
Di masa modern, pendidikan ala kolonial lebih memainkan peranannya dalam kancah pemerintahan nasional, bukan pendidikan ala pesantren. Menurut Nurcholish Madjid, salah satu alasan banyaknya pesantren yang tidak berkembang dikarenakan sistem penjajahan yang cenderung mendiskreditkan kaum pesantren. Seandainya negeri kita ini tidak mengalami penjajahan, mungkin pertumbuhan sistem pendidikan di Indonesia akan mengikuti jalur-jalur yang ditempuh pesantren. Sehingga perguruan-perguruan tinggi yang ada sekarang ini tidak akan berupa UI, ITB, IPB, UGM, UNAIR, atau pun yang lainnya, tetapi mungkin namanya Universitas Tremas, Krapyak, Tebuireng, Bangkalan, Lasem, dan seterusnya. Sebagaimana pertumbuhan sistem pendidikan di negeri-negeri Barat yang tidak mengalami penjajahan, dimana hampir semua universitas terkenal pada mulanya adalah sekolah keagamaan (seminari). ${ }^{24}$ Dalam hal ini, Nurcholish Madjid mengambil contoh misalnya seminari yang didirikan oleh pendeta Harvard, yang kemudian menjadi kampus nomor satu dunia.

Pandangan Nurcholish Madjid di atas, seirama dengan pendapat yang dikemukakan oleh Abdurrahman Mas'ud, bahwa di masa kolonial Belanda, pesantren sangat antipati terhadap Belanda dengan segala bentuk modernisasinya. Akibatnya, pemerintah kolonial mengadakan kontrol dan pengawasan yang ketat terhadap pesantren. Pemerintah Belanda mencurigai institusi pendidikan dan keagamaan pribumi yang digunakan untuk melatih para pejuang militan untuk melawan penjajah. ${ }^{25}$

Akan tetapi, Yudian Wahyudi berbeda dalam melihat apa penyebab pesantren tidak berkembang di masa sekarang (modern). Menurut Yudian faktor penghambatnya bukan hanya soal penjajahan, akan tetapi ada dua penyebab utama. Pertama, ketika itu Inggris, sebagai salah satu pewaris peradaban Islam Andalusia, menjajah Amerika, sedangkan Nusantara dijajah oleh pewaris-pewaris peradaban Islam Andalusia-yaitu Portugis, Spanyol, dan Belanda. Inggris, sebagai salah satu "super power" Barat dengan tradisi Oxford dan Cambridgenya, memiliki segalanya untuk berkembang di Amerika. Inggris mendirikan Oxford University menjelang akhir abad ke-12, suatu momentum yang berbarengan dengan awal dunia Islam membuang “experimental sciences" dari kurikulum madrasah. Di sisi lain, Indonesia tidak punya apaapa. $^{26}$

Kedua, seminari barat mengembangkan "experimental sciences”, tetapi pesantren membuang “applied sciences" dari kurikulum. Di Amerika, "kuda” misalnya berubah menjadi

\footnotetext{
${ }^{24}$ Nurcholish Madjid, Bilik-Bilik Pesantren, h.4

${ }^{25}$ Abdurrahman Mas'ud, Dari Haramain ke Nusantara: Jejak Intelektual Arsitek Pesantren (Jakarta: Kencana Prenada Media Group, 2006), Cet-I, h. 89.

${ }^{26}$ Yudian Wahyudi, Perang Diponegoro; Tremas, SBY dan Ploso, h.21
} 
alat transportasi canggih seperti mobil, kereta api dan tank. ${ }^{27}$ Oleh karena itu, dalam pandangan Yudian Wahyudi, salah satu penyebab mundurnya pendidikan Islam dikarenakan umat Islam hanya terbatas pada mempelajari soal akidah, tetapi hampir "kafir alamiah", hampir tidak pernah menjadikan alam sebagai bagian dari keimanan dan keislaman mereka. Artinya, tidak benar-benar fokus meneliti alam (sains) sebagai sesuatu yang dapat mengantarkan pengetahuan dan pencapaian kepada Allah. Sedangkan orang lain, katakanlah Amerika Serikat, maju karena mereka "muslim alamiah dan insaniah". Mereka banyak meneliti lingkungan, alam raya dan lain sebagainya sebagai tanda kebesaran Allah. ${ }^{28}$ Artinya jelas, pendidikan Islam mundur karena buta ilmu alam, ilmu sosial, dan hanya melek ilmu akidah.

Berangkat dari dinamika dan problematika yang ada di dunia pesantren dan tantangan perubahan zaman yang ada, maka muncullah kemudian pesantren yang berlomba-lomba mendirikan sekolah umum untuk mengikuti tuntutan masyarakat. Sehingga santri tidak hanya belajar pengetahuan agama, tapi juga diharapkan dapat menguasai pengetahuan umum seperti murid-murid di sekolah pada umumnya. Sehingga akses santri dalam melanjutkan pendidikan semakin meluas. Oleh karena itu, saat ini tidak jarang kita temui pesantren-pesantren yang memiliki lembaga pendidikan umum mulai TK, SD, SMP, SMA dan SMK di samping MI, MTs, dan MA. ${ }^{29}$ Meski tetap ada beberapa pesantren yang masih mempertahankan dan memfokuskan kurikulumnya hanya pada mata pelajaran keagamaannya saja. Pesantren yang bersikap demikian, kemudian disebut juga pesantren salafiyyah (tradisional).

Perkembangan dan perubahan yang dilakukan pondok pesantren dalam memadukan mata pelajaran umum dan keagamaan, merupakan bentuk konstalasi dengan dunia modern serta adaptasinya menunjukkan bahwa kehidupan pondok pesantren tidak lagi dianggap statis dan mandeg. Dinamika kehidupan pondok pesantren telah terbukti mampu berkembang dengan keterlibatan dan partisipasi aktif memberikan pelayanan kepada masyarakat dalam berbagai aspek kehidupan. ${ }^{30}$ Pesantren akan senantiasa bergerak dinamis dan progresif karena pesantren

${ }^{27}$ Yudian Wahyudi, Perang Diponegoro; Tremas, SBY dan Ploso, h.22

28 Yudian Wahyudi, Maqashid Syari'ah dalam Pergumulan Politik: Berfilsafat Hukum Islam dari Harvard ke Sunan Kalijaga, (Yogyakarta: Pesantren Nawesea, 2014), h. 27-28

${ }^{29}$ Upaya untuk menyatukan antara ilmu pengetahuan agama dan umum sebenarnya telah dirintis oleh Wahid Hasyim jauh-jauh hari. Ketika Wahid Hasyim menjabat sebagai Menteri Agama Republik Indonesia. Ia melakukan pembaruan pendidikan agama Islam melalui Peraturan Menteri Agama Nomor 3 tahun 1950, yang menginstruksikan pemberian pelajaran umum di madrasah dan memberi pelajaran agama di sekolah umum negeri/swasta. Hal ini semakin mendorong pesantren mengadopsi madrasah ke dalam pesantren. Pesantren semakin lebih membuka kelembagaan dan fasilitas-fasilitas pendidikannya bagi kepentingan pendidikan umum. Pesantren tidak hanya mengadopsi madrasah tetapi juga mendirikan sekolah-sekolah umum. Pesantren Tebuireng Jombang adalah pesantren pertama yang mendirikan SMP/SMA. (Lihat Zamakhsyari Dhofier, Tradisi Pesantren: Studi tentang Kyai, h. 57)

${ }^{30}$ Sa'id Aqiel Siraj, “Pesantren Masa Depan”, (Bandung: Pustaka Hidayah, 1999), h. 181. 
memiliki sebuah adagium: "al-muhâfadzatu 'alâ al-qadîmi al-shâlih wa al-akhdu bi al-jadîdi al-ashlah" dalam setiap perkembangan zaman. Jika kita tinjau lebih dalam lagi, pada dasarnya Islam tidak mengenal dikotomi antara ilmu agama dan ilmu umum seperti matematika, fisika, dll. Karena setiap ilmu pada dasarnya lahir dan datang dari Allah. Baik itu yang diteliti dari ayat qouliyah (al-Quran) ataupun ayat kauniyah (science). Sehingga, muncullah kemudian istilah integrasi ilmu pengetathuan (integral-knowledge).

Dengan demikian jelaslah bahwa pesantren bukan hanya mampu bertahan. Tapi lebih dari itu, dengan penyesuaian, akomodasi dan konsensi yang diberikannya, pesantren pada gilirannya juga mampu mengembangkan diri, dan bahkan kembali menempatkan diri pada posisi yang penting dalam sistem pendidikan nasional Indonesia secara keseluruhan.

\section{Keunggulan Pesantren}

Eksistensi pesantren memang masih mampu bertahan dengan baik sampai saat ini, akan tetapi masih banyak masyarakat yang belum begitu memahami secara utuh apa kelebihan pesantren sebagai lembaga pendidikan di Indonesia, dibandingkan dengan lembaga pendidikan yang lain pada umumnya. Serta apa kunci dan rahasianya pesantren yang dibangun oleh kalangan Nahdliyin mampu mencetak santri-santri yang turut serta menjaga keutuhan NKRI.

Oleh karena itu, di bagian ini penulis akan menjelaskan mengenai beberapa keunggulan pesantren yang belum banyak disadari oleh masyarakat. Keunggulan pertama pesantren adalah do'a kyai, tidak ada pesantren dibangun tanpa do'a kyai. Pesantren belum berdiri pun, seorang kyai sudah berdo'a. ${ }^{31}$ Kyai yang mendo'akan santri-santrinya, bahkan sebelum pesantren itu dibangun, menegaskan bahwa seorang kyai memiliki visi yang jelas dalam menjalankan lembaga pendidikan yang diembannya.

Kedua, kelebihan pesantren adalah santri-santri yang akan menimba ilmu datang dari berbagai daerah (multi-kultur). Tidak seperti sekolah yang pada umumnya, siswa-siswinya cenderung hanya berasal dari lingkungan sekitar (mono-kultur). ${ }^{32}$ Dengan begitu, di pesantren santri sudah terbiasa berinteraksi dengan sesama santri, bahkan guru, dari berbagai latar belakang. Sehingga tidak menimbulkan rasisme dan fanatisme golongan. Bahkan, mereka saling mendo'akan. ${ }^{33}$ Hal inilah yang kemudian melahirkan persaudaraan sesama muslim (ukhuwah Islamiyah), sesama anak bangsa (ukhuwah wathaniyah), dan antar sesama manusia (ukhuwah basyariyah). Saling menghargai perbedaan suku, ras, bahasa, yang ada di lingkungan

\footnotetext{
${ }^{31}$ Yudian Wahyudi, Perang Diponegoro; Tremas, SBY dan Ploso, h.35

32 Yudian Wahyudi, Perang Diponegoro; Tremas, SBY dan Ploso, h.42

33 Yudian Wahyudi, Perang Diponegoro; Tremas, SBY dan Ploso, h.43
} 
pesantren. Hal ini, kemudian diistilah oleh Abdurrahman Wahid (Gus Dur) sebagai "kosmopolitanisme pesantren".

Ketiga, kelebihan pesantren adalah kurikulumnya. Kurikulum di pesantren memiliki ragam mata pelajaran, sekalipun banyaknya mata pelajaran tersebut akan menjadi kelemahan pesantren jika tidak dikelola dengan baik. ${ }^{34}$ Tujuannya mungkin baik, yaitu agar santri-santri mengenal banyak hal yang merupakan perpaduan ilmu agama Islam dengan ilmu pengetahuan umum. Namun demikian, santri menjadi terlalu terbebani. Di sisi lain pendalaman materi tidak tergarap dengan baik karena jam belajar di sekolah juga tidak cukup banyak. ${ }^{35}$ Sehingga praktiknya, menjadi cenderung setengah-setengah. Akan tetapi, jika dioptimalkan dengan baik, ini akan menjadi kelebihan pesantren yang tidak dimiliki oleh lembaga pendidikan pada umumnya. Lebih jauh lagi, menarik kita cermati pendapat Salahuddin Wahid (Gus Solah). Gus Solah berpandangan bahwa penggabungan antara mata pelajaran umum dengan mata pelajaran agama adalah sebuah upaya dari pendidikan Islam untuk membangun dan memadukan antara keindonesiaan dan keislaman. ${ }^{36}$

Kelebihan keempat pesantren adalah hampir seluruh literatur (text book/buku ajar)-nya berbahasa Arab. ${ }^{37}$ Hal itu bisa dilihat dari kitab-kitab kuning yang menjadi rujukan utama dalam proses pembelajaran. Hal tersebut jika dilakukan secara efisien akan melahirkan suatu kemampuan berbahasa arab yang luar biasa. Kemampuan berbahasa arab yang diolah di pesantren akan memuluskan karir akademik santri-santrinya yang hendak melanjutkan pendidikan ke jenjang yang lebih tinggi.

Kemudian keunggulan pesantren yang keenam adalah adanya sistem "sorogan" 38. Sistem sorogan menjadi kekuatan pesantren dibandingkan dengan sistem pendidikan di sekolah, bahkan Perguruan Tinggi sekalipun. Dalam hal ini, pesantren bahkan dapat dikatakan lebih unggul dibandingkan Perguruan Tinggi luar negeri sekalipun. Di McGill bahkan di Harvard, seperti di Sunan Kalijaga dan UGM, juga tidak ada sistem sorogan. ${ }^{39}$

Keuntungan dari sistem sorogan ini berlapis. Pertama, setiap pagi santri-santri sibuk belajar mendalami materi utama: kitab kuning. Mereka dibimbing untuk membaca kitab gundul di hadapan seniornya. Di sisi lain, teman-temannya yang belum maju sorogan mendapatkan

${ }^{34}$ Yudian Wahyudi, Perang Diponegoro; Tremas, SBY dan Ploso, h.67

35 Yudian Wahyudi, Perang Diponegoro; Tremas, SBY dan Ploso, h.68

${ }^{36}$ Salahuddin Wahid, Memadukan Keindonesiaan dan Keislaman, (Koran Republika. 7/12/16).

37 Yudian Wahyudi, Perang Diponegoro; Tremas, SBY dan Ploso, h.46

${ }^{38}$ Sorogan bisa diartikan proses belajar yang langsung dibimbing oleh guru/kyai/snatri senior. Dimana setiap santri menghadap satu-satu pada guru/kyianya untuk membacakan suatu kitab, lalu kyai/guru membenarkan jika ada yang salah

39 Yudian Wahyudi, Perang Diponegoro; Tremas, SBY dan Ploso, h.55 
pengertian lain andaikata mereka belum tahu sebelumnya. Kedua, santri-santri senior sudah dilatih untuk menjadi kyai jauh-jauh hari sebelum mereka pulang kampung untuk mengabdikan ilmu mereka kelak. Ketiga, dengan sistem kaderisasi santri senior ini maka anggaran pun dapat ditekan. Di sisi lain, santri senior sudah dilatih untuk ikhlas dan tawadlu' dalam mengabdikan ilmu mereka. ${ }^{40}$ Di samping itu, santri-santri yang sudah terbiasa belajar di pesantren, menjadi lebih berhati-hati dalam mencerna paham dan pengetahuan keagamaan yang saat ini banyak beredar di alam internet dan website-webiste yang tidak jelas siapa penulis dan darimana sumbernya.

Ketujuh, kelebihan pesantren adalah membentuk santri-santri atau manusia yang memiliki semangat non-materialistik, tidak materialistis, atau bisa kita artikan semangat kesederhanaan. ${ }^{41}$ Semangat non-materialistik ini jika benar-benar ditanamkan secara mendalam kepada para santri, akan sangat bermanfaat dalam menjaga keutuhan NKRI. Karena, banyak sekali golongan yang ingin menghancurkan dan menguasai NKRI karena golongongolongan tersebut haus akan kekuasaan dan kekayaan yang bersifat materialis, seperti pejabatpejabat yang korup dan semacamnya.

Keunggulan-keunggulan yang dimiliki oleh pesantren sebagai lembaga pendidikan dan perannya dalam menjaga keutuhan NKRI, setidaknya berangkat dari 12 prinsip yang melekat pada pendidikan pesantren, yaitu: (1) teosentrik; (2) ikhlas dalam pengabdian; (3) kearifan; (4) kesederhanaan (sederhana bukan berarti miskin); (5) kolektifitas (barakatul jama'ah); (6) mengatur kegiatan bersama; (7) kebebasan terpimpin; (8) kemandirian; (9) tempat menuntut ilmu dan mengabdi (tholabul 'ilmi lil 'ibadah); (10) mengamalkan ajaran agama; (11) belajar di pesantren tidak untuk mencari sertifikat/ijazah saja; dan (12) kepatuhan terhadap kyai. ${ }^{42}$

Potret kehidupan pesantren menurut Dawam Rahardjo telah mampu mencerminkan dan merawat karakter dan tradisi Nusantara, salah satunya sikap "gotong royong". ${ }^{43}$ Pesantren, dengan cara hidupnya yang bersifat kolektif, telah menunjukkan kelihaiannya dalam memadukan nilai-nilai kearifan nusantara dengan salah satu perwujudan dari semangat dan nilai-nilai keagamaan, seperti al-ukhuwah (persaudaraan), al-ta'awun (tolong-menolong), alittihad (persatuan), al-jihad (perjuangan), al-tha'ah (kepatuhan terhadap Allah, Rasul, Ulil Amri dan Ulama).

\footnotetext{
${ }^{40}$ Yudian Wahyudi, Perang Diponegoro; Tremas, SBY dan Ploso, h.56

${ }^{41}$ Nurcholish Madjid, Bilik-Bilik Pesantren, h.99

${ }^{42}$ Abudin Nata, Sejarah Pertumbuhan dan Perkembangan Lembaga Pendidikan Islam di Indonesia, (Jakarta: PT. Grasindo, 2001), h. 113

${ }^{43}$ M. Dawam Rahardjo, Pesantren dan Pembaharuan, Jurnal LP3ES, (Jakarta: 1983), h.9
} 
Oleh karena itu, menurut hemat penulis, jika ada pesantren-pesantren yang mempelopori gerakan makar dan gerakan fundamentalisme untuk menghancurkan kebhinekaan, dan menghapus kearifan lokal Nusantara. Maka, pesantren tersebut telah keluar dari "fitrah" pesantren yang sebenarnya. Pesantren dibangun oleh para pendahulu kita, sebagai ruang untuk melahirkan pemikiran-pemikiran dan ide-ide yang damai dan berkemajuan, bukan ide-ide yang menciptakan kerusuhan dan gelombang konflik.

Adagium yang diciptakan oleh Kyai Hasyim Asy'ari di kalangan pesantren, seperti “Hubbul Wathon Minal Iman”, merupakan sebuah falsafah yang sangat berdasar dan tidak sembarangan. Cinta tanah air, sebagaimana yang diajarkan Kyai Hasyim Asy'ari, tercermin dalam sejarah nabi dan rasul, di mana mereka mencintai tanah air melebihi cinta mereka pada diri sendiri. Hal tersebut, bisa kita lihat misalnya dalam QS. al-Baqarah [2]:126:

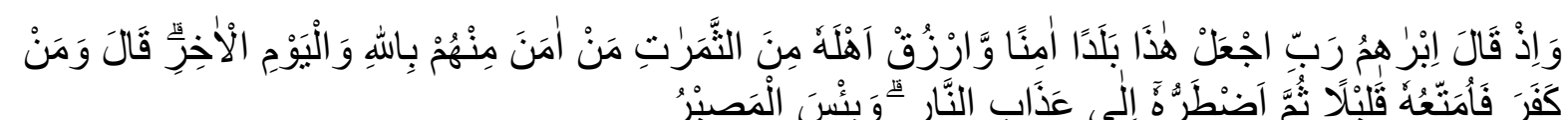
"Dan (ingatlah), ketika Ibrahim berdoa: "Ya Tuhanku, Jadikanlah negeri ini, negeri yang aman sentosa, dan berikanlah rezki dari buah-buahan kepada penduduknya yang beriman diantara mereka kepada Allah dan hari kemudian. Allah berfirman: "Dan kepada orang yang kafirpun aku beri kesenangan sementara, kemudian aku paksa ia menjalani siksa neraka dan Itulah seburuk-buruk tempat kembali". (QS. AlBaqarah [2]:126).

Dilihat dari ayat di atas, ada dua hal yang diidam-idamkan oleh Nabi Ibrahim atas tanah airnya. Pertama, "baladan amina" atau negeri yang aman dan damai bagi penduduknya. Kedua, "war-zuq ahlahu”, yaitu negara yang penduduknya makmur secara ekonomi dan tidak dilanda krisis. ${ }^{44}$ Bahkan dalam ayat di atas, Allah menjelaskan akan memberikan rizki yang berlimpah di dunia bukan hanya kepada penduduk yang beriman, akan tetapi juga kepada penduduk yang tidak beriman. Oleh karena itu, dalam konteks duniawi dan kebangsaan, kita tidak berhak mendiskriminasi seseorang, hanya karena orang itu tidak beriman kepada Allah atau tidak seagama dengan kita. Karena yang berhak menghukumi kekafiran orang-orang yang tidak beriman adalah Allah sendiri nanti di yaumil akhir.

\section{KESIMPULAN}

${ }^{44}$ Ibi Syatibi, Pendidikan Karakter Berbasis Tradisi Pesantren, h.29 
Genealogi munculnya pesantren di Indonesia, dapat dikategorikan ke dalam tiga perspektif. Pertama, pandangan yang menyatakan bahwa pesantren lahir dari tradisi Islam (tarekat), kedua, pandangan yang menyatakan pesantren lahir dari tradisi pendidikan timur-tengah (kuttab), ketiga, pandangan yang menyatakan pesantren lahir dari tradisi pendidikan Hindu (mandala). Perbedaan pandangan tersebut, lahir karena tidak adanya data yang meyakinkan dari masingmasing pihak. Akan tetapi, meski demikian barangkali perbedaan pandangan tersebutlah yang menjadi fondasi utama pesantren dalam membangun kearifan dalam menghargai berbagai macam tradisi dan budaya yang ada. Bahwa pesantren mencerminkan tata nilai dan budaya yang bersifat lintas-tradisi dan lintas-keagamaan.

Sebagai lembaga pendidikan, pesantren sampai saat ini masih bisa mempertahankan dan bahkan mengembangkan eksistensinya. Hal tersebut, dikarenakan pesantren mampu mendialogkan antara pengetahuan keagamaan dengan pengetahuan umum sebagai dua ilmu yang sama-sama berasal dari Allah (integralistik-knowledge). Pesantren mampu menjawab setiap perubahan dan tuntutan zamannya, dengan tetap mempertahankan nilai-nilai lama yang baik dan mengambil nilai-nilai baru yang lebih baik.

Di samping itu, pesantren sebagai lembaga pendidikan tertua di Indonesia, memiliki peran yang besar dalam menjaga keutuhan NKRI. Bukan hanya mengurusi ritual keagamaan dan transformasi pengetahuan semata. Pesantren bukan hanya mengajarkan santri-santrinya mencintai bangsa sebagai sebuah mata pelajarn. Akan tetapi, lebih jauh dari itu, sikap saling menghargai sesama muslin, sesama manusia, dan sesama bangsa, telah diinternalisasikan ke dalam hidup sehari-hari selama mengikuti proses pendidikan di pesantren itu sendiri. 


\section{Daftar Pustaka}

Aly, Abdullah, Pendidikan Islam Multikultural di Pesantren: Telaah terhadap Kurikulum Pondok Pesantren Modern Islam Assalam Surakarta (Yogyakarta: Pustaka Pelajar, 2011)

Aqiel Siradj, Sa’id, Pesantren Masa Depan, (Bandung: Pustaka Hidayah, 1999)

Asrohah, Hanun, Sejarah Pendidikan Islam (Cet. I; Jakarta: Logos Wacana Ilmu, 1999)

Aziz, Abdul, et al., Ensiklopedi Islam IV (Jakarta: Ichtiar Baru Van Hoeve, 1994)

Azra, Azyumardi, Pendidikan Islam: Tradisi dan Modernisasi di Tengah Tantangan Milenium, (Jakarta: Kencana Prenada Media Grup, 2012)

Departemen Agama RI., Nama dan Data Potensi Pondok-Pondok Pesantren Seluruh Indonesia,(Jakarta: Depag RI., 1984/1985)

Dhofier, Zamakhsyarie, Tradisi Pesantren: Studi tentang Pandangan Kyai (Jakarta: LP3ES, 1997)

Madjid, Nurcholish, Pesantren dan Tasawuf, (Jakarta: LP3ES, 1995)

, Bilik-Bilik Pesantren: Sebuah Potret Perjalanan, (Jakarta: Penerbit

Paramadina, 1997) , Islam Agama Peradaban: Membangun Makna dan Relevansi Doktrin Islam

Dalam Sejarah, (Jakarta: Paramadina, 2008)

Mas'ud, Abdurrahman, Dari Haramain ke Nusantara: Jejak Intelektual Arsitek Pesantren (Jakarta: Kencana Prenada Media Group, 2006)

Mastuhu, Dinamika Sistem Pendidikan Pesantren: Suatu Kajian tentang Unsur dan Nilai Sistem Pendidikan Pesantren, (Jakarta: INIS, 1994)

Muhaimin, et al., Pemikiran Pendidikan Islam (Bandung: Tri Genda Karya, 1993)

Nata, Abudin, Sejarah Pertumbuhan dan Perkembangan Lembaga Pendidikan Islam di Indonesia, (Jakarta: PT. Grasindo, 2001)

Rahardjo, M. Dawam, Pesantren dan Pembaharuan, Jurnal LP3ES, (Jakarta: 1983)

Shihab, Alwi, Islam Inklusif, (Bandung: Mizan, 2002)

Syatibi, Ibi, ed. Pendidikan Karakter Berbasis Tradisi Pesantren, (Jakarta: Rumah Kitab, 2014)

Syukur, Fatah, Dinamika Pesantren dan Madrasah (Yogyakarta: Pustaka Pelajar, 2002)

Wahyudi, Yudian, Maqashid Syari'ah dalam Pergumulan Politik: Berfilsafat Hukum Islam dari Harvard ke Sunan Kalijaga, (Yogyakarta: Pesantren Nawesea, 2014) , Perang Diponegoro; Tremas, SBY dan Ploso, (Yogyakarta: Cakrawala Media, 2012) 
Pesantren: Genealogi, Dinamika, dan Nasionalisme

Ziemek, Manfred Pesantren dalam Perubahan Sosial (Jakarta: P3M, 1986)

Zuhairini, ed. Sejarah Pendidikan Islam, (Jakarta: Bumi Aksara, 1992) 